\title{
低密度ポリエチレンの電気伝導に与える 一軸延伸の影響
}

正員 舛 井 正義 (茨城大)
正員 長 坂 秀 雄 (茨城大)
正員 矢

\section{1.まえがき}

ポリエチレンは電気絶縁材料として優れているばか りでなく，工業材料として広く用いられているので多 くの研究肪ある。しかし，高分子材料特有の複雑な構 造のため，物性と微細構造の関係は十分解明されてい るとは言えない。

結晶性高分子の力学的特性が延伸により強く影響を 受けるととは良く知られている。乙れ結晶性高分子 固体の微細構造が延伸によって変化し，内部構造が未 延伸物と異なるためである。著者らは一軸延伸による 高分子の微細構造の変化住目し，微細構造の变化之 電気伝導 ${ }^{(1)(2)}$ や絶縁破壊電压に与える影響 ${ }^{(3)(4)}$ 亿つい て研究してきた。電気伝導仪関して，高密度ポリエチ レンフィルムの場合，導電率は延伸率 $30 \%$ でわずか に隇少するが，それ以上の延伸では次第に增加する。 これは一軸延伸による $c$ 軸配向が生じ，分子銷間の 結合を強化し，キャリア移動度を增加するためで市 る。 $\gamma$ 線照射低密度ポリエチレンの場合は，一軸延伸 により電気伝導が減少した。延伸率 $60 \%$ までは延伸 によるエントロピーの減少や深いトラップ加增加し て，渚しく導電率を小さくするが，更に延伸するとラ メラが細分化し浅いトラップを生じ，ホッピングサイ 卜が増加してキャリア移動度が增加し，乙のため導電

Effect of Uniaxial Elongation on Electrical Conduction in Low Density Polyethylene. By Masayoshi Masui, Member, Hideo Nagasaka, Member (Department of Electrical Engineering, Ibaraki University) \& Kichinosuke Yahagi, Member (Department of Electrical Engineering, Waseda University). 多并正羲：正員，莰城大学工学部電気工学科

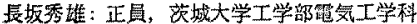
矢作宫之助: 正具, 早稚田大学理工学部電気工学科
率が増加する。低密度ポリエチレンは高密度ポリエチ

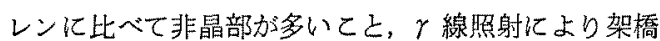
が生じやすいととが，延伸による構造变化に大きく影 響しているあのと考元る。

著者の一人は，一軸延伸が絶縁破髙に与える影響に ついてむ検討しているが，絶緑破填については非晶部 の㯺密化によるフリーがリウムの減少が著しい影響を 与元る(3)(4)。

分子量は電気伝導だけでなく，高分子の機械的性質 に影響を与える。例えば，Andrew 氏 氏 $^{(5)}$ は分子量が大 きいほど応力緩和弾性率が大きいと言い，Capaccio 氏(6)はヤング係数に影響を与えるとしている。

本研究は，密度がぼば等しく分子量の異なる4 桯の 低密度ポリエチレン試料を用いて，インフレーション フィルムを製作して，20 $20^{\circ}$ で一軸延伸を行ない，一 朝延伸が電気伝導に与える影響について，結晶配向， 密度など内部微細構造や熱刺激電流測定によるトラッ プなどの検討から考察を試みたものである。なお，高

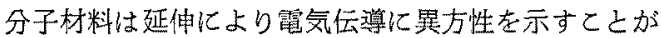
報告されているが皇)(8)，本論文では延伸方向化垂直な 方向の電気伝導のみを取扱うことにする。

\section{2. 実験方法}

〈2・1〉供試料表1亿示すように，分子量の異 なる 4 種の低密度ポリエチレンをインフレーション法

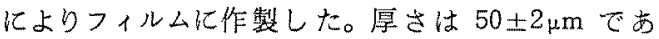
る。添加剤佶含まれていない。

〈2.2〉 延伸方法 前報(1)(2) と同一にした。すな わち，延伸温度 $20^{\circ} \mathrm{C}$ でマシン力向に一軸延伸し，延 伸速度 $7 \mathrm{~mm} / \mathrm{min}$ とした。延伸後は金属製わくで延伸 
表 1 試料の特性

Table 1. Properties of samples.

\begin{tabular}{l|c|c|c|c}
\hline 試 料 & $A$ & $B$ & $C$ & $D$ \\
\hline 密度 $\left(\mathrm{g} / \mathrm{cm}^{3}\right)$ & 0.920 & 0.923 & 0.923 & 0.923 \\
$M I$ & 0.25 & 1.0 & 3.0 & 5.0 \\
$\bar{M}_{n}$ & 23,400 & 21,400 & 20,600 & 18,120 \\
$\bar{M}_{W}$ & 112,600 & 94,800 & 97,200 & 76,400 \\
$\bar{M}_{W} / M_{n}$ & 4.8 & 4.4 & 4.7 & 4.2 \\
\hline
\end{tabular}

状態のままフィルムを固定した。 $l_{0}$ を延伸前の試料 長, $l$ を延伸後の試料長上すると, 延伸率は $\left(l-l_{0}\right) / l_{0}$ $\times 100 \%$ で定義される。

$\langle 2.3\rangle$ 電気伝導の測定前報(1)(2) と同一にした。 すなかち，応力緩和を考慮して一軸延伸後 1 時間以上 経過後から電流測定を行なった。印加電源には皘層乾 電池を用いて，印加電界が $1.47 \times 10^{4} \mathrm{~V} / \mathrm{cm}$ （この領 域ではオーム則が成立することが確認されている）に なるように調整した。この測定に用いた電界の強さは 便宜上用いられたもので，特に選ばれたものではな い。電流はエレクトロメータ（タケダ理研 TR-8641） を用いて測定し，10 分值を用いて電気伝導を諭ずる ことにした。10 分值を用いた理由は，過渡電流項が かなりりさくなるためである。

〈2.4〉赤外二色比による配向測定尔リエレ ンの変形機構について，赤外二色比に上る小野木氏 ら(9)の研究があるので参考にした。前報(1) 之同㥞な方 法を用いて赤外二色比を求めた。ただし，本研究では 偏光子にワイヤーグリッドタイプ（前報に使用した $\mathrm{AgCl}$ に比べて透過率が儤れている）を用いて，720 および $730 \mathrm{~cm}^{-1}$ における吸收を測定し，二色比から 配向関数 $F$ を求文，延伸率と配向の関倸を示した。 な执， $F_{\alpha}$ は結晶の $a$ 軸， $F_{\beta}$ は結晶の” $b$ 軸， $F_{\varepsilon}$ は結晶の $c$ 軸の延伸方向への配向走す。 $F=1$ は 完全配向， $F=0$ はランダム配向， $F=-0.5$ は釷直 配向を示す。

$\langle 2 \cdot 5\rangle$ 熱刺激電流の測定 $\langle 2 \cdot 2\rangle$ 節延伸方法の項 で述べた方法により，試料を $30 \%$ 延伸し，24 時間以 上延伸状態を保持後, 試料の緊張を解放し, 銀ペイン トを用いて直徍 $20 \mathrm{~mm}$ の電極を付けた。銀ペイント を 3 時間以上自然乾澡させて後, 熱刺激電流(TSC 上 略記) 測定に用いた。 Kobayashi 氏ら(10) (著者の一人 と共同研究者）は延伸ポリエチレンを緊張状龍で固定 してTSC を測定したが，今回は Kobayashi 氏らの

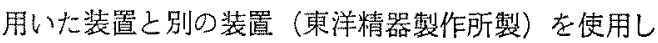
たので，緊張状態では測定が困難なため，試料を延伸 後 3 睦間以上緊張を保持して後，緊張を解放した試料 を用いて TSC 湘定を行なった。電界励起により電荷

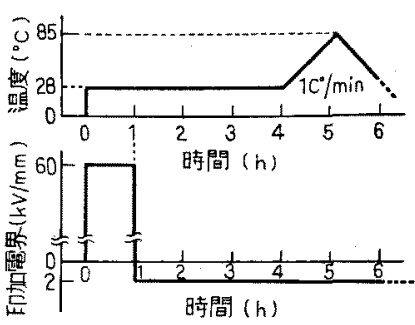

困 1 TSC 測定手順

Fig. 1. Scheme of the time chart for TSC measurement.

注入中に高電圧的加による放電を避けるため，クライ オスタットを乾燥空素で満たした。図1亿TSC 測定 手順を示す。まず，電界励起によりトラップに電子注 入を行なうため，励起電界 $60 \mathrm{kV} / \mathrm{mm}$ を1時間印加 し，次にコレクティングバィアス電界 $2 \mathrm{kV} / \mathrm{mm}$ を䀴 加しながら，3時間短絡した。この間，充電電流は無 視できるほよ゙小さくなる。その後，電流を測定しなが ら昇温速度 $1^{\circ} \mathrm{C} / \mathrm{min}$ で常温加ら $85^{\circ} \mathrm{C}$ まで昇温した。 $85^{\circ} \mathrm{C}$ でヒータの電源を切り, 自然冷却しながら降温 時の電流を测定した。降温時の電流を伝導電流之考 え, 昇温時の電流加ら降温時の電流を差し引いて真の TSC とした。なお，電流測定は振動容量形電位計（夕 ケダ理研 TR-84) を用い，電流のランダム雑音を除 去するため, 利得 5 , 時定数 $4 \mathrm{~s}$ のアクティブローパ スフィルタ增幅器を通し，記録計を用いた。

\section{3. 実験結果と考察}

$\langle 3.1\rangle$ 微細構造微細構造の変化について, 前 報(1)で屯触れたが，再び考察上必要であるから触れる ことにする。

試料フィルムはインフレーションフィルムであるの で，赤外二色比よりみるとオリジナル試料はごくわず か $a$ 朝配向している。ポリエチレンの配向について は小野木氏 ${ }^{(9)}$ ，河合氏 ${ }^{(11) ，}$ 松元氏ら ${ }^{(12)}$ ，笹野氏ら ${ }^{(13)}$ の報告がある。笹野氏らは高密度ポリエチレンフ ィルムの高温および常温延伸を行ない，配向，長周期 (微結晶の周期的な配列に㧍ける微結晶の重心間の平 均距離), 収縮, 密度, 結晶化度の変化を測定し, 次の 結論艺得ている。すなわち，常温延伸では降伏点（延 伸率 15 20\%）までは長周期は增大し，それからやや 平らな部分があって，30 70\% 延伸付近から延伸之 共に減少する。長周期の增加は非晶相の延伸が挙げら れる。また，長周期の緩やかな隇少牥ラメラの融解あ るいは破壞が生ずるためと考えられる。高温延伸では 融解再結晶化の可能性むあると述へている。 


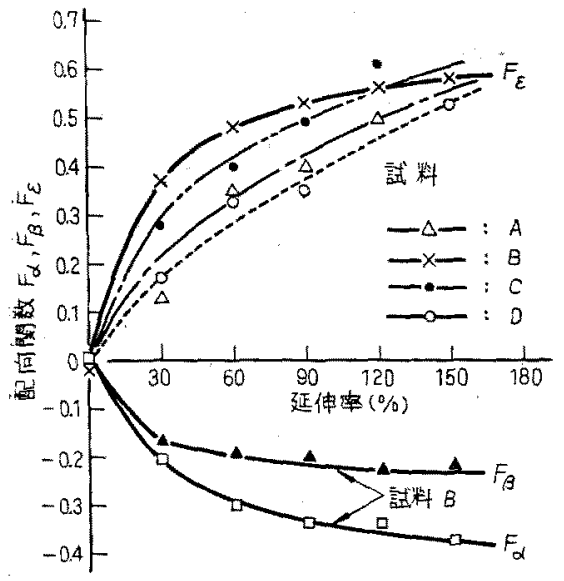

图 2 延伸率已 $a$ 朝， $b$ 軸， $c$ 郵の 配向関数の関保

Fig. 2. Relation between orientation functions of $a$-axis, $b$-axis and $c$-axis, and draw ratio.

次に配向について論ずる。試料フィルムを一軸延伸 几た之きの亦外二色比に上る配向測定結果を四 2 亿示 す。との結果加，次第に $c$ 軸似配向していくこと， および試料 $B, C$ 之試料 $A, D$ の二つのグループに 分類できる。試料 $B$ 加最む配向しやすいてと走し ている。MIが大きいはど分子量か心さく，結晶化し やすい之言われている(14)。

密度变化について考察する。沖中氏ら ${ }^{(15)}$ は，本研 究に用いたすの上同一な試料老用いて，延伸による密 度变化を測定し，图3の結果を報告している。試料 $A$, $B$ の場合估延伸倸占り密度加增加するが; 試料 $C, D$ の場合仙滅少することがかかる。分子量の迬いが微 細構造の変化汇影留することを示している。之の他， 延伸試料の密度老测定した例としては，Bettelheim 氏ら(16)纪高密度ポりエチレンを延伸し，密度の增加

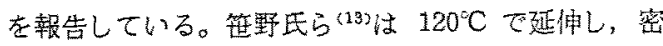
度の增加を報告している。岡島氏ら ${ }^{(17)}$ は $128^{\circ} \mathrm{C}$ で延 狎し，密度の減少を報告している。山口氏ら ${ }^{(18)}$ は低 密度ポリエチレンを $30^{\circ} \mathrm{C}$ で延伸し，延伸後 $70^{\circ} \mathrm{C}$ で 1時間アニーリングした試料では延伸率 $50 \%$ で最小 值を持占，更化延伸すると密度が増加するこ之を示し ている。それぞれの測定者間の測定条件の違いも市

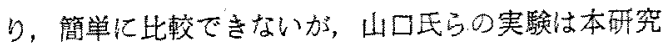
の条件に類议ており，参考になるすのである。

〈3.2〉一軸延伸と電気伝導青䈎氏ら (19)はポり エチレンの電気任導はホッピング伝尊でよく説明でき るととを報告している。常温ではキャリアが可で苦る 加現在なお難しい問題であるが，電子であるという仮

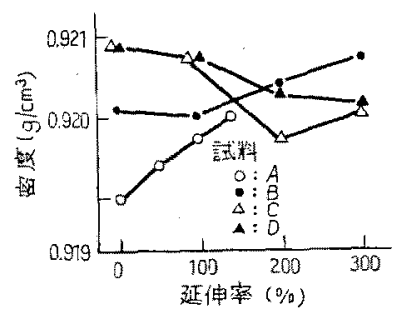

图了一軸延伸化上る密度の変化(15)

Fig. 3. Density variation due to uniaxial drawing.

定のもとに議論を進める。

Lewis 氏(20)亿よれば，電子化よる電流減亳機構の 一つは次のようである。すなわち，電流 I，トラップ 間の平均自由時間 $\tau_{j}$ とすると，

$$
I \propto \exp \left(-t / \tau_{f}\right)
$$

キャリアがトラップ中に滞在している時間 $\tau_{\mathrm{t}}$ は

$$
\tau_{t}=\nu^{-1} \exp \left(E_{t} / \kappa T\right)
$$

と表わされる。山は振動数 (an attempt to escape frequency) 之言われ，キャリアが捕捉された之きと 自由時のエントロピー差を表初す。延伸はエントロピ

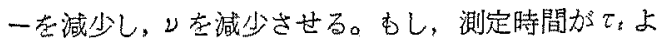
り小さいとき，一度トラップされたキャリアは電導に 寄与しない(深いトラップとなる)。測定時間がて。 り大きいときは，捕捉さ机たキャリアは電導带に再が 放出される(线いトラップとなる)。トラップレベルを 単一之考元て，キャリ了の真の移動度 $\mu$ ，見加けの移 動度能と劣ると

$$
\mu_{\varepsilon}=\frac{\mu \tau_{f}}{\left(\tau_{f}+\tau_{t}\right)} \simeq \frac{\mu \tau_{f}}{\tau_{f}}, \quad \tau_{f} \ll \tau_{f}, \sigma z き
$$

すなっち、

$$
\mu_{e}=\mu \tau_{f} \nu \exp \left(-E_{t} / \kappa T\right)
$$

この上うに Lewis 氏徒えば，見かけの移動度は減 少する。本実唤の減旁電流測定結果志图 4 图 7 K 示す。こ机らの図は Lewis 氏の結果(20)k基づき片対 数に描玑九たが直線にはならない。これは良く知られ ているように，高分子のトラップ準㕸は単一レベルで はないととに起因すると思和れる。

表 2 亿試料 $B$ O減衰電流加剆定時間を分割し，

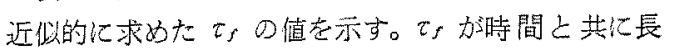
くなっていくととがわかる。キャりアが近くのトラッ プから遠方へ上捕招されるためと考えられる。

次化，延伸已 $\tau_{f}$ の変化を表了汇示す。延伸比上り $\tau_{f}$ 加隇少すると之が加る(試料 $A$ を除く)。民の 理由よして，延伸による trap site の増加に起因する と考えられる。試料 $A$ については4種の試料中分子 


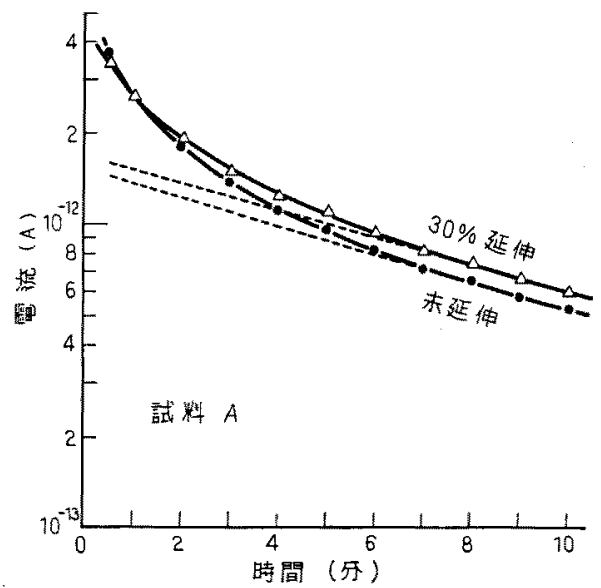

図 $430 \%$ 延伸試料 $A$ の減裹電流

Fig. 4. Decay current for $30 \%$ drawn specimen $A$.

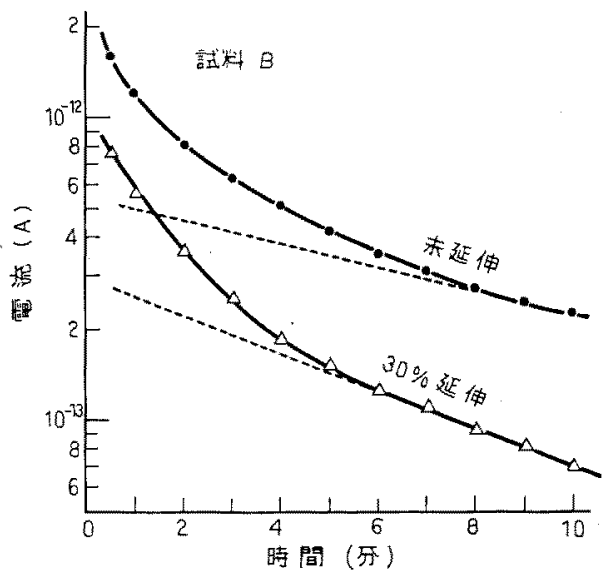

图 $530 \%$ 延伸試料 $B$ の減衰電流

Fig. 5. Decay current for $30 \%$ drawn specimen $B$.

表 2 未延伸試料 $B$ の $\tau_{f}$ の時間依存性

Table 2. Time dependence of $\tau_{f}$ on undrawn specimen $B$.

\begin{tabular}{c|c||c|c}
\hline 淿定眭間 $(\mathrm{min})$ & $\tau_{f}(\mathrm{~s})$ & 测定眭間 $(\mathrm{min})$ & $\tau_{f}(\mathrm{~s})$ \\
\hline $0.5 \sim 1$ & 1.6 & $5 \sim 6$ & 6.9 \\
$1 \sim 2$ & 2.6 & $6 \sim 7$ & 7.0 \\
$2 \sim 3$ & 3.8 & $7 \sim 8$ & 8.8 \\
$3 \sim 4$ & 4.8 & $8 \sim 9$ & 9.8 \\
$4 \sim 5$ & 6.5 & $9 \sim 10$ & 11.1 \\
\hline
\end{tabular}

量が最む大きく，密度が最も小さいととから微結晶の 大きさが小さく(14)，延伸率 $30 \%$ で仿他の試料に比へ て非晶相の伸び（毉密化）による微細構造の変化が大 きいため， $\tau_{f}$ が他の 3 種の試料と巽なった挙動を示 していると考えられる。

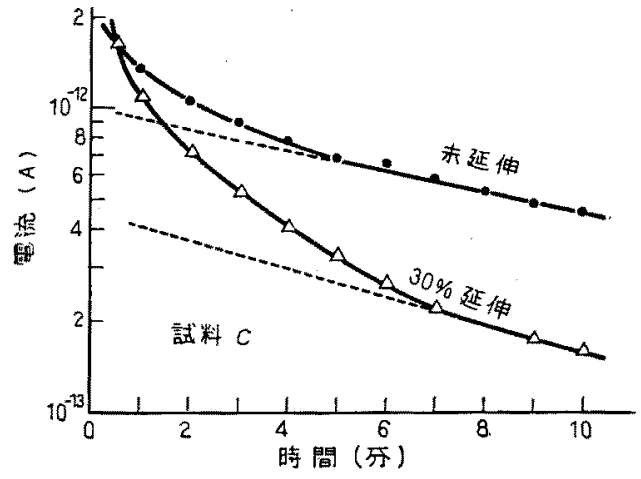

因 $630 \%$ 延伸試料 C の減衰電流

Fig. 6. Decay current for $30 \%$ drawn specimen $C$.

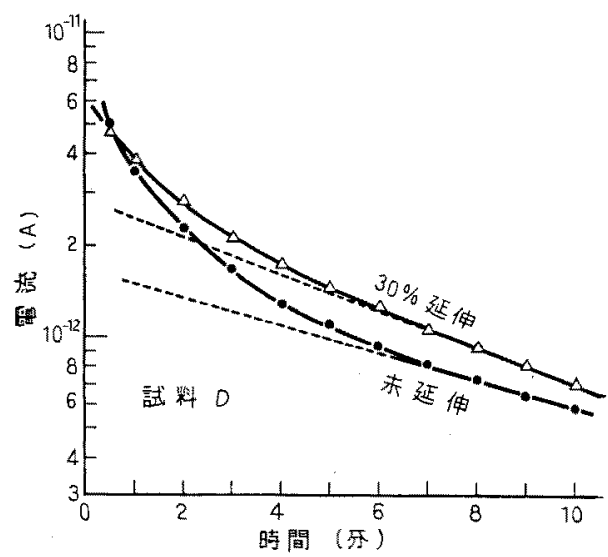

图 $730 \%$ 延伸試料 D 減衰電流

Fig. 7. Decay current for $30 \%$ drawn specimen $D$.

表 3 延役による $\tau_{\rho}$ の変化

Table 3. Variation of $\tau_{f}$ due to uniaxial drawing.

\begin{tabular}{|c|c|c|c|c|}
\hline 試 料 & $A$ & $B$ & $C$ & $D$ \\
\hline 末 延 低 & 9.2 & 11.1 & 12.3 & 9.5 \\
\hline 30\% 延伸 & 9.7 & 7.0 & 9.4 & 7.1 \\
\hline
\end{tabular}

延伸は前述のように，まず非晶相を引き伸ばす。こ れは結晶相と非晶相間の様相を变えるととになる。

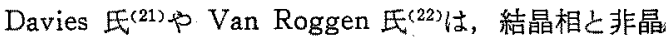
相の界面に物理的トラップが存在すると報告してい る。降伏点（延伸率 $12 \%$ ）を越えて $30 \%$ 延伸した試 料の内部には新しい界面が作られていると考えられ る。乙れは一部の微結晶が延伸方向に $c$ 軸配向を始 めているが，周囲の微結晶や非昆相の妨害を受けて十 分配向できない状態であり，このような新しい界面は 


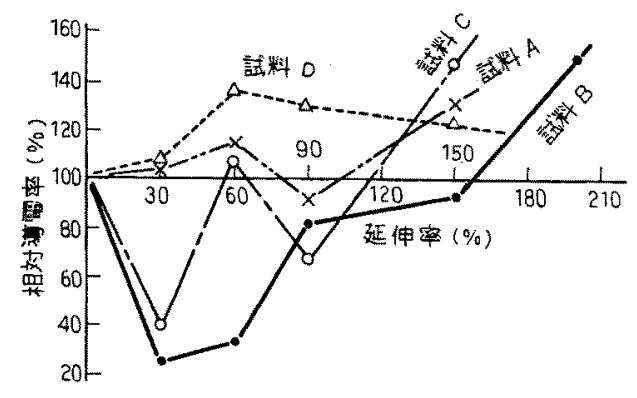

図 8 電気伝導の一軸延伸の影響

Fig. 8. Effect of uniaxial drawing on electrical conductivity.

酸素を吸着し，トラップとなっている可能性もある。 Boustead 氏ら (23) は酸素をトラップ源しして考え，実 揗的移動度を低下させる可能性は十分あるとしてい 万。

延伸率 $60 \%$ で好更にc 軸配问が進み，笹野氏ら(13) の那究によれば高密度ポリエチレンの延伸では長周期 が最大值を示す領域である。この延伸率では Molecular tie chainが相当強力に結晶相を結んでいる考え られるが, 一方, 分断される Molecular tie chain屯 増加しつつあると思われる。Patel 氏ら ${ }^{(24)}$ P Takai 在ら ${ }^{(25)}$ は，結晶相と非晶相の界面に作られる“Physical Cavity や橋かけが梁いトラップの原因となるとし ている。これらのトラップは導電率の隇少の原因とな る。

次に，延伸率之導電率 (10 分檤) D関係を図 8 亿 示す。㲘電率は未延伸試料の伝導率乙比較して表示し

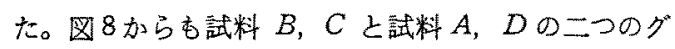
ループに分けるととかでる。との点については、 〈4.4〉節で分子量の影響という観点加ら考察する。倦 述するように，試料 $B, C$ は延伸率 $30 \%$ で深いトラ ップを生じ，延伸率の增加と共に浅いトラップに転じ ていき，試料 $A ， D$ では浅いトラップを生じている と考无られる。筷野氏ら(13)は延伸率の小さい間は婹周 期が增加するが，更に延伸すると長周期力゙減少するこ とを報告して㕲り，乙の状態ではラメラの崩壊が生じ ていると考えられる。ラメラの崩買はホッピングサイ トの增加となり、ホッピングサイト間の距離を小さく し，電気伝導を増加していくと考えられる。

〈4.3〉熱刺激電流によるトラッブの測定利り エチレンの TSC 测定は高松氏ら (26)(27)によって行な われているが，著者の一人间は延伸試粼の TSC 測 定を行ない，てれまでに次の結論を得ている。室温以 上の測定で $35,45,60^{\circ} \mathrm{C}$ にピークを生ずるが, $45^{\circ} \mathrm{C}$ のピークは著しく大きい。これらのピークは結晶分散

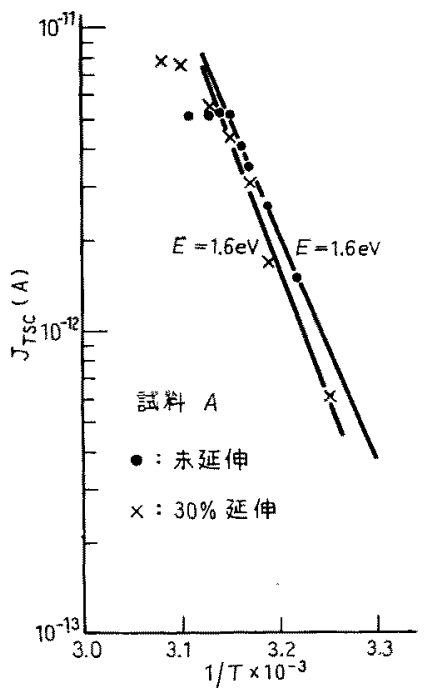

图 9 試精A の未延伸と $30 \%$ 延伸試料の TSC プロット

Fig. 9. TSC initial rise plot in undrawn and $30 \%$ drawn specimen $A$.

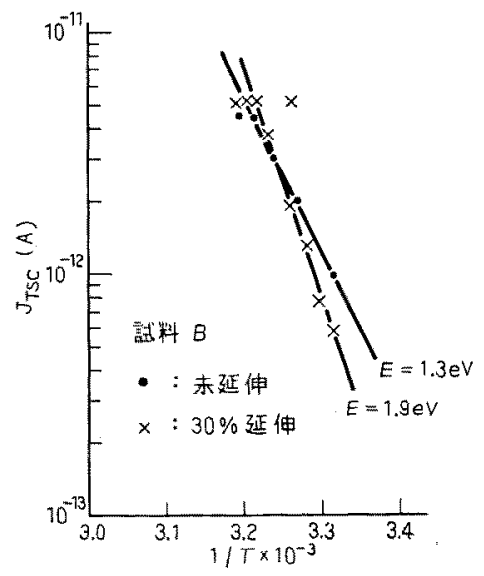

図 10 試料 $B$ O來延伸之 $30 \%$ 延伸試料の TSC プロット

Fig. 10. TSC initial rise plot in undrawn and $30 \%$ drawn specimen $B$.

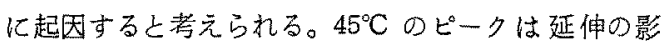
響老受ける。延伸率 $200 \%$ までの試料は末延伸試料に 比へてビークが增加しだこのピークは延伸により增 加したトラップから解放された電荷キャリアによるも のであると考えだ・ドップの実体优延伸によるラメ ラの細分化や再結晶化によって作られる“Physical Cavity”によって説明できるししている。

前述のように, 分子墨の異なる試料を延伸し，電気 伝導を测定すると著しい差暴がある。この結果を理解 


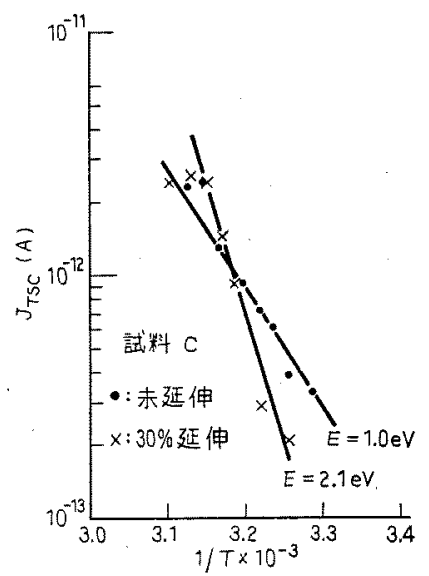

図 11 試料 C の未延伸と $30 \%$ 延伸試料の TSC プロット

Fig. 11. TSC initial rise plot in undrawn and $30 \%$ drawn specimen $C$.

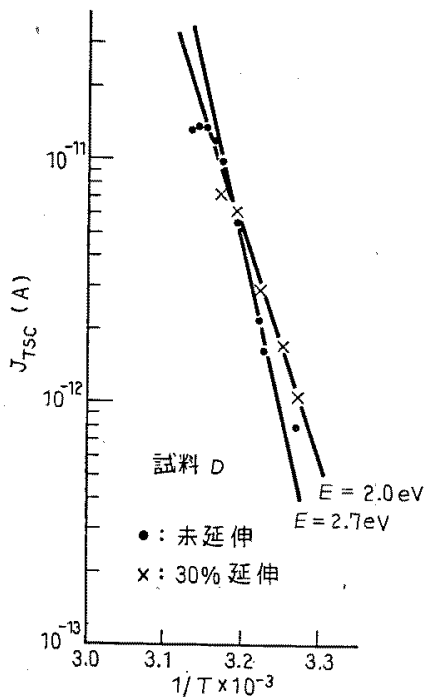

図 12 試料 $D$ の未嫁伸之 $30 \%$ 延伸武料の TSC プロット

Fig. 12. TSC initial rise plot in undrawn and $30 \%$ drawn specimem $D$.

するため，TSC 測定を行なった。TSCのデータから 活性化エネルギーを求めるため, Initial Rise 法を使 用する。図 9 12 因化 $J_{\text {TSC }}$ 之温度 $1 / T$ の関係を示 す。表 4 亿活性化エネルギーを示す。試料结電気伝導 挙動に著しい差異のある延伸率 30\% のむのを使用し た。

てれらの実験結果杜，延伸により試料 $A ， D$ の場 合は活性化エネルギーが減少し, 試料 $B, C$ の場合 は增加することを示した。これより試料 $A ， D$ の場
表 4 末延伸之 $30 \%$ 延伸䟼料の TSC 加ら 求められた活性化エネルギー

Table 4. Activation energy obtained from TSC for undrawn, and $30 \%$ drawn samples.

\begin{tabular}{c|c|c||c|c|c}
\hline 試料 & 末延伸試料 & $30 \%$ 延伸試料 & 試料 & 米延伸試料 & $30 \%$ 延伤試料 \\
\hline$A$ & 1.6 & 1.6 & $C$ & 1.0 & 2.1 \\
$B$ & 1.3 & 1.9 & $D$ & 2.7 & 2.0 \\
\hline
\end{tabular}

表 5 TSC の面積加ら計算された解放電荷の変化 Table 5. Externally observed charge variation calculated from area of the TSC peak.

\begin{tabular}{|c|c|c|c|}
\hline 料 & 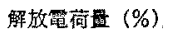 & 試料 & 解放電荷醍 $(\%)$ \\
\hline$A$ & 130 & C & 172 \\
\hline$B$ & 87 & $D$ & 127 \\
\hline
\end{tabular}

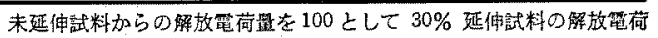
䭪を表わす。

合は延伸により浅いトラップを生じ，試料 $B, C$ は 喍いトラップを生じているととがわかる。

表 5 に TSC 曲線加ら求められた解放電荷を示す。 試料 $B$ の場合を除いて，延伸によりトラップ電荷が 增加していることがわかった。Nikolskii 氏らら ${ }^{(28)}$ が分 子運動と電子トラップとの関係を発表して以来，その 関速性については多くの研究がある。

高松氏ら ${ }^{(26)(27)}$ は，TSC が極大を示す温度は粘弾 性，熱膨脤率，NMR などの測定加ら得られる分子運 動，転移現象を示す温度域に対応すると述へている。

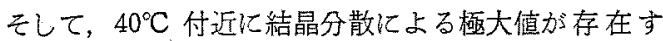
るとしている。

以上より，一軸延伸を行なうととによって分子銷不 整による“Physical Cavity” が結晶界面に生じてト ラップの梁さが変わり，キャリアの解放が促進される

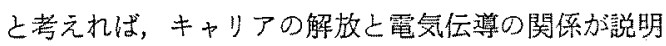
できる。

〈4.4〉電気伝導に対する分子量の影響 次化分 子量の影響について考察する。延伸に上る電気伝導へ の影響は, 試料 $B, C$ と $A, D$ のグループに分け られる。これらの挙動は TSC による活性化エネルギ 一の違いによって説明できる。しかし, 密度変化は試 料 $A, B$ はやや類仪しているが， $C, D$ とは相違が ある。乙机らの変化は偶然注生じたものではなく，分 子量の違いによる結果であると考えられる。分子量と 分子量分布が応力ーひずみ特性に影響を及ばすととが 知られている(29)。

一般䎲ある分子量以下では諸特性が低く，ある分子 量範囲で諸性質が増大し, 分子量の大きいところで最 大値に漸近する゙(30)。Lawton 氏らら ${ }^{(31)}$ はポリエチレン 
の引っ張り特性が数平均分子睹之共に増大し，分子量 約 20,000で極大を通り，数平均分子量が更に增加方 ると徐々に低下することを認めている。本研究に用い た試料 $B$ とC の数平均分子量が 20,000 に近いこ とは, Lawton 压らの結果との関連性加類推され與味 深い。試料 $A$ と $D$ が微細構造の点で異なっている にすかかわらず，電気伝導の点では見掛社上類似の挙 動をとる。この点について現在明確な理由を見つける ことができないが，試料 $A$ の場合は分子量が大き く，分子鎖のからみ合いが多い上考元られ，延伸を堌 加させる上， Molecular tie chain は切断されやす 认。一方, 試料 $D$ の場合は分子量が小さいので，分 子鎖のからみ合いも解けやすく，結昆相と非晶相の界 面が変化して新しい界面を生ずるので他の試料と異な った挙動を示すと考允られる。

延伸による微結晶の配向については赤外二色比によ り測定できた。非晶相については，秩序がないという 説上あるという説がある。延伸によって中間相ができ るとも言われている(33)。非晶相の秩序を測定した Yoda 氏ら ${ }^{(34)}$ の最近の報告もある。非晶相の配向につ いて偏光けい光分光光度計により測定した例 ${ }^{(32)}$ あ るが、非常に複雑である。

\section{5.むすび}

四つの分子量（数平均分子量 $A=23,400, B$ $=21,400, C=20,600, D=18,120)$ の異なる低密度 ポリエキレンフィルムを一軸延伸し，電気伝導上微細 桡造の関係を追究し，次の結論を得た。

分子量の異なる試料によって一軸延伸の影響は異な る。しかし， $B$ 亡 $C$ は類似の挙動を示した。これら の導電率は延伸率 $30 \%$ で最小値を示し，更に延伸す ると漸増した。 $A$ の場合 $90 \%$ までは变化が小さく， 150\% では著しく堌加した。 $D$ では 60〜150\%でや や減少する傾向を示し，他の試料と傾向が著しく变わ

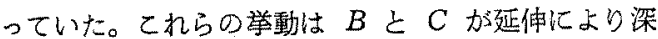
いトラップを，Aと $D$ が线いトラップを生ずること に起因するとすれば比較的良く説明できる。このとと はTSCの测定より求めた活性化エネルギーとも良く 一致する。これらの変化は，分子量の違いによる分子 銷の流動性の違いによって配向や分子分断が異なり， “Physical Cavity”に違い它生ずる。これらはトラ ップサイトになるので，導電性に著しい影響を与年 b。

終りに，試料作成に御協力いただいた日本石油化学 株式会社，赤外二色比の測定に御協力いただいた日立 製作可那珂工場 井上 隆主任，松平俊次主任技硬，
桑名 勉氏，荈城大学理学部化学教室 古賀ノブ子助 教授，仰野義晴助手，いろいると御討論いただいた 早称田大学理工学部大太義路助教授, 同矢作研究室 沖中 踼氏，東 誠司氏など多くの方々の赤好意とご 協力による成果であることを報告し，厚く标礼申し上 げます。

(昭和 55 年 10 月 16 日受付，同 56 年 8 月 10 日再受付)

\section{文献}

（1）多井・矢作：「高密度ポリエチレンの延役による槛造変化と

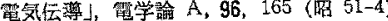

(2) M. Masui, H. Nagasaka \& K. Yahagi: "Effect of elongation on electrical conduction in Gamma-rays irradiated low density polyethylene", Japan J. Appl. Phys., 17, 1719 (1978)

(3) S. Mita \& K. Yahagi: "Effect of elongation on dielectric breakdown strength in polyethylene", ibid., 14, 197 (1975)

(4) K, Yahagi \& Y. Maeda: "Temperature dependence of electrical impulse breakdown strength in elongated polyethylene film ", ibid., 16, 1259 (1977)

(5) R.D. Andrews \& A.V. Tobolsky: "Elastoviscous properties of polyisobuthylene", J. Polymer Sci., 7, 221 (1951)

(6) G. Capaccio, T. A. Crompton \& I. M. Ward: "Draw. ing behavior of linear Polyethylene", ibid., 18, 301 (1980)

(7) S. Hirota: "Anisotrophy study of electrical conduction in oriented polymers [",J.Appl. Phys., 50, 3003 (1979)

(8) S. Hirota: "Anisotropy study of electrical conduction in oriented polymers If", ibid., 50, 3007 (1979)

（9）小野木・浅田・高末：「応力ーひずみ一赤外二色性の同時测定

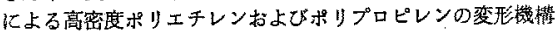
の研究人, 材料, 16，746 (昭 42-9)

(10) S. Kobayashi \& K. Yahagi: "Thermally stimulated current in elongated low density polyethylene film", Japan J. Appl. Phys., 18, 261 (1979)

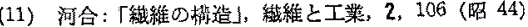

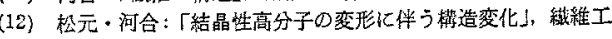
学，20，937 (昭 42)

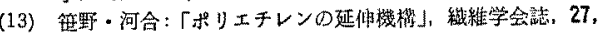
1 (昭 46-1)

(14) L. H. Tung \& S. Buckser: "The effect of molecular weight on the crystallinity of polyethylene".J. Phys. Chem, 62, 1530 (1958)

（15）沖中・大木・矢作：「ポリエチレンフィルムのモロブロシ

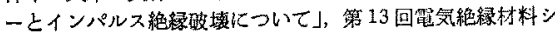
ンボジウム予稿集, p. 53 (昭 55)

(16) F.A. Bettelheim \& R.S. Stein: "The change in density of low pressure polyethylene on stretching ", $J$. Polymer Sci., 31, 523 (1958)

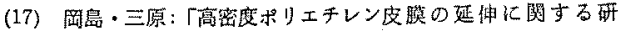
究了，䋐維学会綕，23，457 (昭 42-10)

(18）山口・柳川・木村：「趆伸低密度ポリエチレンフィルムの非

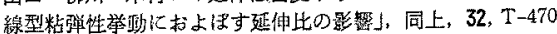
(䀡 51-11)

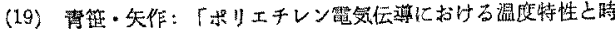
閔特性の相関」，籍学誌，91，743 (昭 46-4)

(20) T. J. Lewis: "Some recently observed conduction phenomena in insulating solids", 第 9 回雪気緮娽材料シン

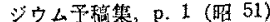

(21) D.K. Davies: "Carrier transport in polyethylene", J. Phys. D: Appl. Phys., 5, $162(2972)$ 
(22) A. Van Roggen: "Electronic conduction of polymer single crystals", Phys. Rev. Lett., 9, 368 (1962)

(23) I. Boustead \& A. Charlesby: "Thermoluminescence in polyethylene I. Electron traps", Proc. Roy. Soc. (London), A 316, 291 (1970)

(24) G.N. Patel \& A. Keller: "Crystallinity and the effect of ionizing radiation in polyethylene", $J$. Polymer Sci. Polym. Phys. (edited), 15, 303 (1975)

(25) Y. Takai, K. Mori, T. Mizutani \& M. Ieda: "Investi. gation of traps in $\gamma$-irradiated polyethylene by photostimulated detrapping currnt analysis", Japan $J$. Appl. Phys., 15, 2341 (1976)

(26) 高松・深田：「ポリエチレンおよびテフロンエレクトレッ

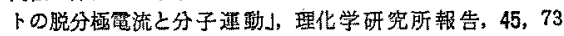
(䧂 44)

(27) 高松・深田：「ポリエチレン姑よびパラフィン類のエレクト レット热分析1, 闹上, 46, 131 (明 45)
(28) 10) を通Lて, V.G. Nikolskii \& N, Ya. Buben: Proc. Acad. Sci., USSR. Phys. Chem., 147, 896 (1960)

(29) J.A. Yanko: "Physical properties of fractions of GR$S$ and their vulcanizates". J. Polymer Sci, 3, 576 (1948)

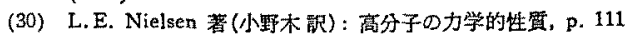
(昭 47) 化学同人

(31) E. J. Lowton, J.S. Balwit \& A.M. Buche: "Properties of irradiated Polyethylene", Ind. Eng. Chem., 46, 1703 (1946)

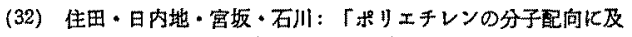

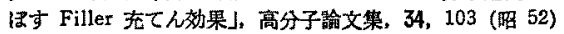

(33)，和田：高分子の固体物理，p. 242 (昭 46) 培風館

(34) O. Yoda, I. Kuriyama \& A. Odajima: "Interchain ordering in amorphous solid polyethylene", Appl. Phys. Lett., 32, 18 (1978) 